\title{
Nutritive Content of Sheep, Goat, and White- tailed Deer Diets on Excellent Condition Rangeland in Texas
}

\author{
F.C. BRYANT, M.M. KOTHMANN, AND L.B. MERRILL
}

Abstract

A one-year study was initiated in August, 1975, to examine the nutritive content in diets of four kinds of sympatric ruminants on excellent condition rangeland of the Edwards Plateau in Texas. Sheep, Angora goat, and Spanish goat diets were collected from animals fitted with permanent esophageal cannulae. Nutritive content of white-tailed deer diets was estimated by hand-plucking representative forages as the deer were observed grazing them. Mean, annual levels of crude protein (CP) were similar among the four kinds of animals. All diets were lowest in CP during January and February, with livestock diets showing higher levels than deer. However, deer diets were higher in CP than sheep and goat diets during spring and summer. During January and February, the livestock diets warranted only minimum protein supplementation while deer diets were significantly below recommended levels. Digestible energy (DE) levels were higher for sheep diets than for diets of either goats or deer. Similarly, the goat diets were higher in DE than deer diets. The DE levels were generally adequate for sheep but critically low for Angora goats during late gestation. Deer diets were very low in DE during winter and again in early summer, coinciding with the period of peak lactation. Energy would appear to be more limiting for animal production than protein under the conditions of this research.

Several kinds of herbivores are sympatric on the Edwards Plateau of Texas. The smaller herbivores using the rangeland are sheep, Angora goats, Spanish goats, and whitetailed deer (Odocoileus virginianus L.). Sheep and Angora goats were introduced at the turn of the century, while Spanish goats are a more recent introduction. White-tailed deer have long been part of the endemic fauna.

Sheep differ from goats in their foraging preference (McMahan 1964). There are indications that Spanish and Angora goats express different forage preferences under certain conditions (C.A. Taylor, pers. comm.); however, these differences apparently were minor on excellent condition rangeland (Bryant et al. 1979). Differences in observed forage preferences and in nutrient requirements of the different kinds of animals suggest that each may require different management to obtain optimum production.

Good range management practices have generally been thought to benefit animal production. Thus, as more producers strive to improve their ranges, it is important to determine, seasonally, nutrients that may limit animal production on ranges in higher condition classes. Information

Authors are assistant professor, Range and Wildlife Management, Texas Tech University, Lubbock 79409; professor, Department of Range Science, Texas A\&M University, College Station 77843; and professor in charge, Texas A\&M University Research Station at Sonora 76950. Portions of this research were submitted in partia fulfillment of requirements for the Ph.D. degree in Range Science at Texas A\&M University by Bryant. The authors gratefully acknowledge the assistance of Charles $A$.

Taylor and Ed Huston of the Texas Agricultural Experiment Station.

This report is TA 14973 from the Texas Agricultural Experiment Station.

Manuscript received March 26, 1979.

on nutrient levels in diets from excellent condition rangeland was not available for the Edwards Plateau.

The objective of this study was to determine the nutritive content of diets selected by sheep, Angora goats, Spanish goats, and white-tailed deer on an excellent condition rangeland.

\section{Study Area and Methods}

The field research was conducted at the Texas A\&M University Agricultural Research Station located on the Edwards Plateau near Sonora, Texas. Topography, climate, and vegetation there have been described by Smeins et al. (1976) and Bryant and Kothmann (1979). Briefly the study area occurs at $735 \mathrm{~m}$ elevation, has an average rainfall of $65 \mathrm{~cm}$, and a growing season of 235 days.

The study area was an 8-ha enclosure located within a 33-ha pasture and was described in detail by Bryant et al. (1979). From 1948 to 1970 , the pasture received light continuous grazing (16 ha/animal unit [au]) with a 2:1:1 au ratio of cattle, sheep, and Angora goats, respectively. In 1970, it was rootplowed and seeded with both introduced and native grass species. Stocking rate was subsequently increased to $6.5 \mathrm{ha} / \mathrm{au}$ and the Merrill grazing system (four pastures, three herds, 12 mo grazing followed by 4 mo rest) was applied. To take advantage of high forage production, the stocking rate was further increased to $5.4 \mathrm{ha} /$ au in 1974 and to 5.2 $\mathrm{ha} / \mathrm{au}$ in 1977. This pasture was considered to be in excellent range condition and has consistently yielded the greatest production per animal of any pasture on the Sonora Research Station (L.B. Merrill, pers. comm.).

Diets of all four kinds of animals were sampled on five consecutive days each month for $1 \mathrm{yr}$, beginning August 20, 1975. The livestock and deer were fasted overnight before each collection day. Bryant et al. (1979) reported how the animals were handled and the collection regime.

Livestock diets were obtained from four each of Angora goats, Spanish goats, and sheep fitted with permanent esophageal cannulae described by Taylor and Bryant (1977). Due to losses, a total of 8 Angora goats, 11 Spanish goats, and 9 sheep were uséd to collect diet samples throughout the study. Each sampling day, the extrusa samples were collected in screen-bottomed bags, thoroughly handmixed, and a sub-sample was taken and stored at $-20^{\circ} \mathrm{C}$ for chemical analysis.

Twenty, wild-trapped white-tailed deer fawns were raised and trained following the guidelines of Reichert (1972). Two adapted to the rigors of transporting and handling and could still be allowed free range of the study area without the confines of a leash (Fig. 1). At project initiation one fawn was 5 mo old while the other was 4 mo. Thus, the deer used were in their most critical nutritional stage of life, weanling to yearling age (4 to 17 months).

Samples of species and their plant parts were hand-plucked each collection day to represent those selected by the deer as they were observed grazing the study area. The basic criteria suggested for use of hand-plucking, the selection of plant parts (Halls 1954) and 


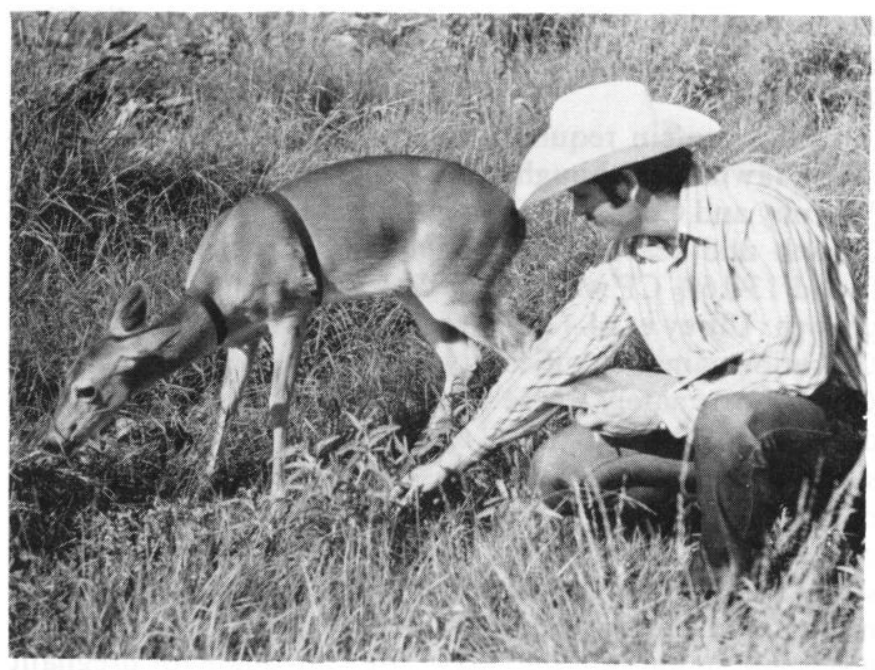

Fig. 1. Hand-plucking was used to obtain representative samples of plants eaten by deer at the Sonora Research Station.

use of lightly grazed areas (Cook 1964), were observed in this study. Hand-plucked samples were frozen within $1 \mathrm{hr}$ of collection and stored at $-20^{\circ} \mathrm{C}$.

All diet and hand-plucked samples were freeze-dried $\left(-50^{\circ} \mathrm{C}\right.$, 20-100 microns of pressure) and ground in a Wiley mill to pass a $1-\mathrm{mm}$ screen. They were composited across individual animals within days and across days within individual animals for each kind of animal within collection periods. Chemical analyses included organic matter $(\%)$, organic nitrogen $(\%)$, and in vitro digestible organic matter $(\%)$.

Crude protein (CP) was calculated by multiplying total organic nitrogen $\times 6.25$; digestible energy $(\mathrm{DE})$ was estimated by the procedure described later. All values reported are expressed on an oven-dry, organic matter basis to avoid variability from ash contamination by saliva.

Organic matter was determined by ashing duplicate samples in a muffle furnace at $550^{\circ} \mathrm{C}$ for $5 \mathrm{hr}$. Nitrogen determination, expressed as crude protein, followed the micro-Kjeldahl procedure (A.O.A.C. 1970). In vitro digestible organic matter was determined following the procedures of Van Soest (1970). Sheep and goat samples were incubated $48 \mathrm{hr}$ using steer innocula. The handplucked deer samples were incubated for $48 \mathrm{hr}$ using innocula from one of the deer used during the study and later fitted with a rumen fistula. Following the incubation, samples were killed with mercuric chloride and stored in a refrigerator until they were refluxed in a neutral detergent solution. Digestible energy was calculated from in vitro digestible and neutral detergent extractable organic matter using the formula:

$$
\text { D.E. }=\frac{(G-H)(I)}{(G)(J)} \times K
$$

where:

$$
\begin{aligned}
\text { D.E. = } & \text { digestible energy in } \mathrm{kcal} / \mathrm{kg} \text { organic matter. } \\
\mathrm{G}= & \text { organic matter }(\%) \times \text { oven-dry weight }(\mathrm{g}) \text { of } \\
& \text { sample. } \\
\mathrm{H}= & \text { weight }(\mathrm{g}) \text { of organic matter residue after in vitro } \\
& \text { digestion and neutral detergent extraction. } \\
\mathrm{I}= & \text { known in vivo digestibility of a standard forage. } \\
\mathrm{J}= & \text { batch in vitro digestibility of a standard forage. } \\
\mathrm{K}= & \text { constant of } 4,000 \mathrm{kcal} / \mathrm{kg} \text { of digestible organic } \\
& \text { matter. }
\end{aligned}
$$

Anderson (1977) reported all laboratory procedures in greater detail.

In order to evaluate the effect of innoculum source, 20 deer samples from all seasons of the year were incubated with steer innocula. Digestibility coefficients of all deer samples were adjusted to correct for the significant difference $(P<.05)$ between steer and deer innocula using the following regression equation:

$$
y=-.001+.871 x
$$

where:

$$
\begin{aligned}
& y= \text { uncorrected digestion coefficient of hand-plucked } \\
& \text { deer samples incubated with steer innocula } \\
& \mathrm{x}= \\
& \text { uncorrected digestion coefficient of hand-plucked } \\
& \text { deer samples incubated with deer innocula }
\end{aligned}
$$

Nutrient content of diets was subjected to analysis of variance to detect significant differences among kinds of animal, periods, and the kind $X$ period interaction. Differences among means were evaluated with Duncan's multiple range test (Dixon and Massey 1969).

\section{Results and Discussion}

\section{Crude Protein}

Mean annual CP content of the diets selected by the four kinds of animals was similar (Table 1). However, changes in availability of forage and associated dietary shifts induced seasonal fluctuations in the levels of $\mathrm{CP}$ for each kind of animal (Fig. 2).

Table 1. Annual means for crude protein (\%) and digestible energy (kcal/ kg) in diets collected from Angora goats, Spanish goats, sheep, and white-tailed deer on the Sonora Research Station during 1975-76.

\begin{tabular}{lcc}
\hline \hline Kind of animal & $\begin{array}{c}\text { Crude protein } \\
(\%)\end{array}$ & $\begin{array}{c}\text { Digestible energy } \\
(\mathrm{kcal} / \mathrm{kg})\end{array}$ \\
\hline Angora goat & 11.1 & $2283^{\mathrm{b}}$ \\
Spanish goat & 11.1 & $2278^{\mathrm{b}}$ \\
Sheep & 10.9 & $2492^{\mathrm{a}}$ \\
White-tailed deer & 11.3 & $2027^{\mathrm{c}}$ \\
\hline
\end{tabular}

'No significant difference $(P>.05)$ was found between dietary levels of $\mathrm{CP}$. ${ }^{2}$ Means in the same column followed by different letters are significantly $(P<.05)$ different.

Sheep, goat, and deer diets were relatively constant in CP from late summer until November when diets began to decline (Fig. 2). During January and February crude protein levels ranged from 7.1 to $8.7 \%$, the lowest levels observed during the study. Crude protein levels in the diets of all animals increased markedly when forb growth began in spring (Bryant et al. 1979). Deer diets showed dramatic increases in CP content, especially in April when the handplucked diets approached $18 \%$, which was higher $(P<0.05)$ than CP levels of any livestock diets. Percent CP in all diets declined in May as forb standing crop increased (Bryant et al. 1979). Kothmann (1968) noted no decline in crude protein levels of sheep diets from April to May. However, for Angora goats, Malechek (1970) reported a decline from April to May in dietary crude protein similar to that found in this study. These variations are probably a function of different stages of plant maturity in May resulting from different growing conditions. Usually, structural carbohydrates increased and percent $\mathrm{CP}$ decreases with increased plant maturity.

June normally is hot and dry and all animals shifted their diets to browse or grass as forbs dried-up (Bryant et al. 1979). This shift was reflected in reduced CP content of all diets (Fig. 2). Crude protein content of diets increased in July when unseasonably cool, rainy weather prevailed, along with the removal of the non-test animals from the pasture for a 4-mo rest period. This produced grass 

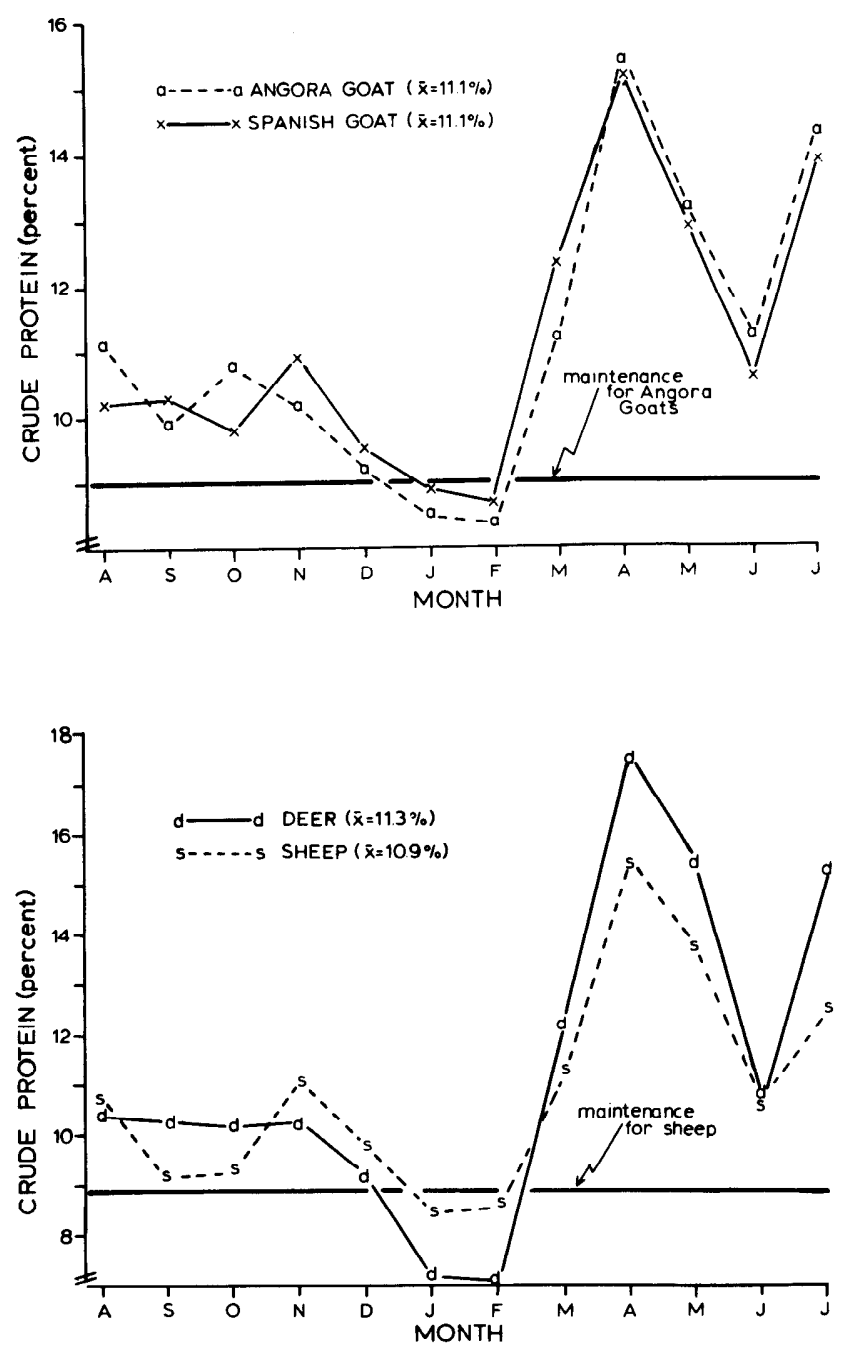

Fig. 2. Crude protein levels (\%) in diets selected by Angora goats, Spanish goats, sheep, and white-tailed deer grazing excellent condition rangeland on the Sonora Research Station during 1975-76.

regrowth which was of high quality due to the rain and also was more available because the non-test livestock were removed from the pasture.

According to Huston et al. (1971), Angora goats require not less than $9.0 \% \mathrm{CP}$ regardless of weight or physiological status. The $\mathrm{CP}$ requirements for gestation, lactation, and growth vary from 10.0 to $13.3 \%$ depending upon weight. Percent CP required by Spanish goats, though unknown, is likely lower than for Angoras since Angoras produce mohair and Spanish goats do not. Thus, under excellent range conditions, Angora and Spanish goat diets appeared to contain sufficient $\mathrm{CP}$ for maintenance in all months except January and February (Fig. 2). Although this deficiency was slight, minimal protein supplementation would be recommended for producing animals (growing kids or pregnant females). Rangeland in low condition classes may require more protein supplement for longer periods due to the reduced diversity of high-quality plants and inadequate forage quantity.

Sheep require $8.9 \%$ CP for maintenance (N.R.C. 1975). Their diets were at or above maintenance in all autumn months and would have derived little benefit from supplement unless they had been in late gestation during January and February (Fig. 2). Researchers in other localities have also reported that $\mathrm{CP}$ content of sheep diets was not limiting to animal production (Arnold et al. 1966; Bedell 1971; Wilson 1976).

Crude protein requirements for white-tailed deer, especially fawns are thought to be higher than for livestock. Murphy and Coates (1966) considered $12 \% \mathrm{CP}$ adequate for growth and reasonable production. French et al. (1956) found $13-16 \% \mathrm{CP}$ was required by young deer for optimum growth. Ullrey et al. (1967) reported fawns receiving a $13 \%$ CP ration gained significantly faster than those receiving $8 \%$ $\mathrm{CP}$. Unfortunately, these results have been compiled from deer where the dietary level of CP was held constant and not subject to seasonal fluctuations that free-ranging deer experience. Also, the energy value of the rations was given little consideration. Regardless, diets selected by fawns in this study may have been below their CP requirements for optimum growth from August through March (Fig. 2). The CP levels late in autumn may have been adequate for pregnant does in early gestation. However, there was an especially critical period in January and February when deer diets contained as little as 7\% CP. Milford and Haydock (1965) reported $7 \% \mathrm{CP}$ was the minimum level required by sheep for positive nitrogen balance. At least $8 \% \mathrm{CP}$ was needed for maximum cellulose digestion in lambs (Church 1972). Since diets were hand-plucked and actual CP levels in deer diets were probably higher, the hand-plucked estimates may represent the minimum. However, the low levels observed in this study indicate a nutritional problem for growing fawns.

\section{Digestible Energy}

Sheep selected diets higher $(P<.05)$ in DE than did goats or deer (Table 1). Digestible energy in Angora and Spanish goat diets did not differ significantly, but deer diets were lower $(P<.05)$ in $\mathrm{DE}$ than goat diets.

There was a significant interaction of kind of animal by collection period. Digestible energy content of all diets generally declined from August through January, but deer diets continued to decrease through February (Fig. 3). These reductions in DE were associated with increased browse in diets, primarily leaves and twigs of plateau oak (Quercus virginianus var. fusiformes [Small] Sarg.), and reduced amounts of grasses and forbs. However, during January, D.E. remained low even when grass increased in all livestock diets by an average of $15 \%$ (Bryant et al. 1979). Thus diets shifted from predominantly browse to about equal proportions of grass and browse (Bryant et al. 1979). This shift apparently did not result in an increase in DE in the diets (Fig. 3). During February, when grass dominated sheep and Angora goat diets, DE increased significantly. Digestible energy in Spanish goat diets also increased in February; however, their diets were still lower $(P<.05)$ in $\mathrm{DE}$ than either Angora goat or sheep diets. Spanish goats selected nearer a 50:50 grass:browse mixture in February (Bryant et al. 1979) and the oak browse depressed DE levels. Deer selected primarily browse through the winter months and their lowest dietary level of $\mathrm{DE}(1,806 \mathrm{kcal} / \mathrm{kg})$ was recorded during February.

The availability of cell walls to a ruminant is largely a function of lignification, which depresses digestibility (Van Soest 1967). Cell walls of browse are highly lignified, approaching $15 \%$ in some browse species (Wilson et al. 1971). Both Kothmann (1968) and Malechek (1970) found lignin content of diets was positively correlated with browse consumption. Therefore, high amounts of browse in diets 

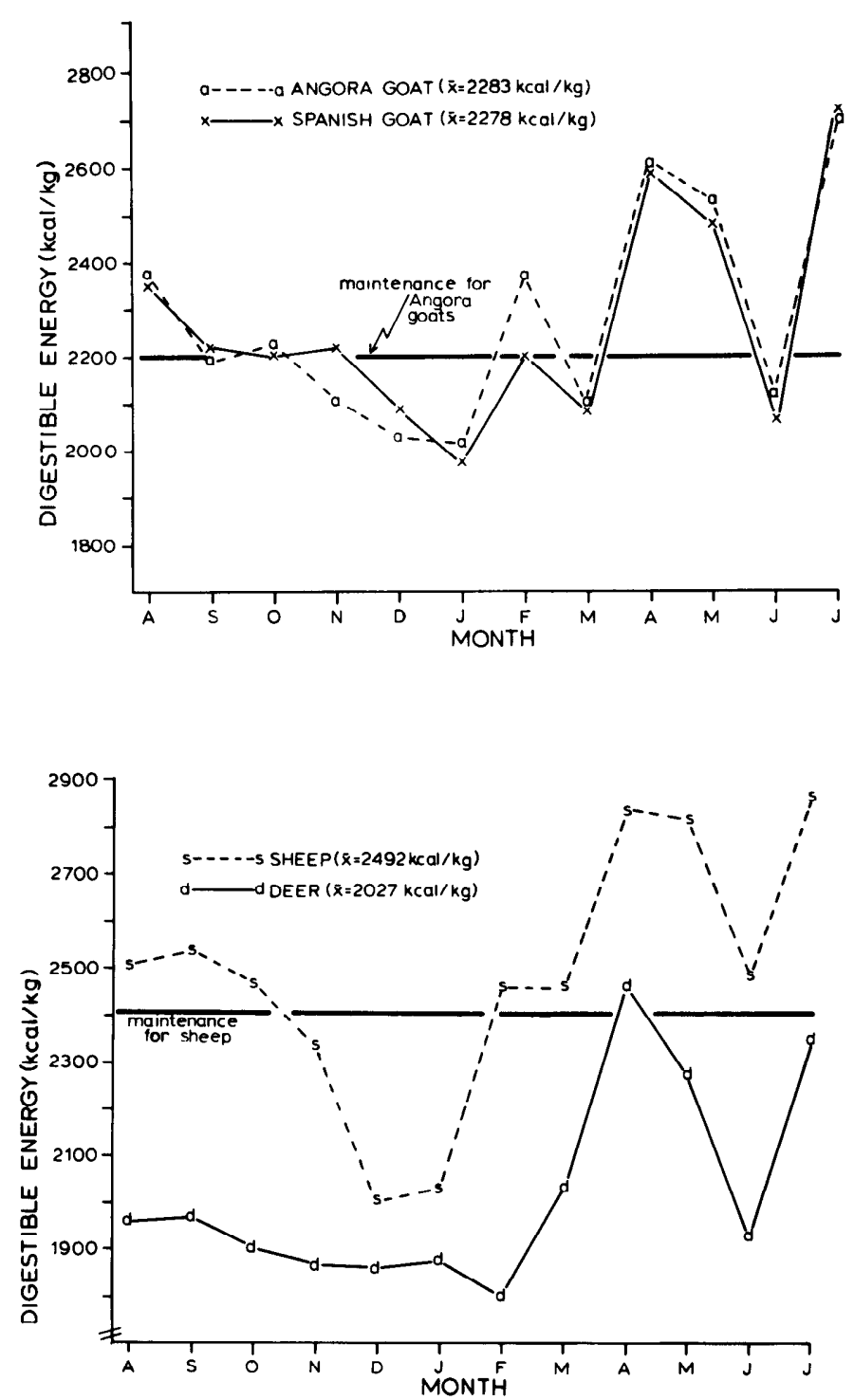

Fig. 3. Digestible energy levels $(\mathrm{kcal} / \mathrm{kg}$ ) in diets selected by Angora goats, Spanish goats, sheep, and white-tailed deer grazing excellent condition rangeland on the Sonora Research Station.

generally results in low digestibility (Wilson et al. 1979), and thus, low DE.

In March when forbs (Bryant et al. 1971) and CP content increased in all diets, DE increased significantly $(P<.05)$ only in deer diets. Levels of DE in goat diets actually decreased while DE in sheep diets remained constant. Evidently, the increase in forbs was not the reason for the observed increase of DE in deer diets. Grass use decreased in Angora goat diets, remained constant in sheep diets, and increased slightly in Spanish goat and deer diets (Bryant et al. 1979). The increase in $\mathrm{DE}$ in deer diets may be explained either by the increased use of succulent grass, the ability to select higher quality forb species, or both.

Goat diets were relatively low in DE from December through March. This period coincides with late gestation since Angora goats are generally bred to kid in March. Van der Westhuysen and Roelofse (1971) reported that long term sub-maintenance energy feeding from mid- to late gestation increased abortion rates of both habitual aborters and apparently normal females. Consequently, it may be necessary on the Edwards Plateau to supplement energy during winter, especially if goats are known to be consuming large amounts of Plateau oak.

Digestible energy levels in the diets of all kinds of animals increased significantly during April. Sheep diets remained high in DE during May while goat and deer diets declined. This was attributed to low browse content in diets of sheep $(2-5 \%)$, while goat diets were as high as $25-35 \%$ browse. Since most sheep and goats are bred for spring lambing or kidding, the higher DE in spring diets would accompany their period of heavy lactation.

Browse increased sharply in diets of all kinds of animals during June, corresponding to the hot, dry weather (Bryant et al. 1979). Digestible energy in goat and deer diets, which contained more than $30 \%$ browse during June, dropped to critically low levels comparable to those observed in December and January. Although sheep diets also decreased in DE, the levels were comparable to those in late summer or late winter. This suggests DE was critically low not only in winter but also during late spring-early summer. The latter period corresponds to the time when white-tailed deer normally are in heavy lactation.

Digestible energy increased in the diets of all kinds of animals in July as favorable weather prevailed and percent grass and forbs in diets increased and browse decreased. Summers in Texas usually remain hot and dry. Thus continued low energy levels in deer diets during summer may be partly responsible for an August-September die-off of young deer which is frequently experienced (Marburger and Thomas 1965).

From the data gathered in this study, energy appears to be the major limiting nutrient on excellent condition rangeland. Assuming energy requirements of $2,200 \mathrm{kcal} / \mathrm{kg}$ for Angora goats weighing $36 \mathrm{~kg}$ (Huston et al. 1971), diets in this study did not meet minimum levels for maintenance of Angora goats in November, December, January, March, and June. Information was not available as to the energy requirements for Spanish goats. A 70-kg ewe requires 2,400 $\mathrm{kcal} / \mathrm{kg}$ of feed ingested for maintenance (N.R.C. 1975). Diets contained sufficient energy to meet the requirements for ewes on all dates except in November, December, and January (Fig. 3). Digestible energy also appeared low in February and March for ewes in late gestation bred to lamb in March, but was adequate for heavy lactation by April. But, livestock in good condition going into winter may be able to cope with minor energy shortages by catabolizing fat depots.

Digestible energy content of deer diets probably would not have provided the $173 \mathrm{kcal} / \mathrm{kg} \mathrm{BW}^{.75}$ required for optimum growth of fawns or the $160 \mathrm{kcal} / \mathrm{kg} \mathrm{BW}^{.75}$ required by pregnant does, assuming does and fawns select similarly in the quality of the diets (Ullrey et al. 1969, Thompson et al. 1973). These low estimates of $D E$ for deer suggest a need for refining techniques to determine DE content of their diets. Even so, the comparatively low levels observed in June were indicative of critically low levels of DE for lactating does, growing fawns, and maturing bucks.

\section{Conclusions}

Livestock diets from rangeland in excellent condition appeared to contain levels of CP acceptable for maintenance and production. Small amounts of protein supplement probably would have been beneficial during January and February. Deer diets also were lowest in CP during the 
winter months and intensive deer herd management would necessitate supplemental protein at this time. Supplemental feeding of deer, however, should be accompanied by a harvest of surplus animals.

Energy appeared to be marginal at times during summer and early autumn and deficient during late autumn and winter for all four kinds of animals. The lactating female deer may require energy supplementation during early summer. Angora goats require additional energy during late gestation (December, January, and February) to improve kid crops and overall reproductive performance, especially during dry winters when goats eat large amounts of Plateau oak.

\section{Literature Cited}

Anderson, D.M. 1977. Standing crop, diets, travel, and weight changes under short duration and continuous grazing. Ph.D. Diss. Texas A\&M Univ., College Station. 180 p.

Arnold, G.W., J. Ball, W.R. McManus, and I.G. Bush. 1966. Studies on the diet of the grazing animal. I. Seasonal changes in the diet of sheep grazing on pastures of different availability and composition. Aust. J. Agr. Res. 17: $543-556$.

Association of Official Agricultural Chemists. 1970. Official methods of analysis. (11th ed.) Ass. Off. Agr. Chem., Washington, D.C. 1015 p.

Bedell, T.E. 1971. Nutritive value of forage and diet of sheep and cattle from Oregon subclover-grass mixtures. J. Range Manage. 24: 125-133.

Bryant, F.C., and M.M. Kothmann. 1979. Variability in predicting edible browse from crown volume. J. Range Manage. 32: 144-146.

Bryant, F.C., M.M. Kothmann, and L.B. Merrill. 1979. Diets of sheep, Angora goats, Spanish goats and white-tailed deer under excellent range conditions. J. Range Manage. 32: 412-417.

Church, D.C. 1972. Digestive physiology and nutrition of ruminants. Vol. 2 Nutrition. Oregon State Univ., Book Stores, Inc. Corvallis. 801 p.

Cook, C.W. 1964. Symposium on nutrition of forages and pastures: Collecting forage samples representative of ingested material of grazing animals for nutritional studies. J. Anim. Sci. 23: 265-270.

Dixon, W.J., and F.J. Massey. 1969. Introduction to Statistical Methods. McGraw-Hill Book Co. 637 p.

French, C.E., L.C. McEwan, N.D. Magruder, R.H. Ingram, and R.W. Swift. 1956. Nutrient requirements for growth and antler development in the white-tailed deer. J. Wildl. Manage. 20: 221-232.

Halls, L.K. 1954. The approximation of cattle diet through herbage sampling. J. Range Manage. 7: 269-270.

Huston, J., M. Shelton, and W.C. Ellis. 1971. Nutritional requirements of the Angora goat. Texas Agr. Exp. Bull. 1105: 1-16.
Kothmann, M.M. 1968. The botanical composition and nutrient content of the diet of sheep grazing on poor condition pasture compared to good condition pasture. Ph.D. Diss. Texas A\&M Univ., College Station. 60 p.

Malechek, J.C. 1970. The botanical and nutritive composition of goat diets on lightly and heavily grazed ranges in the Edwards Plateau of Texas. Ph.D. Diss. Texas A\&M Univ., College Station. 61 p.

Marburger, R.G., and J.W. Thomas. 1965. A die-off in white-tailed deer of the Central Mineral region of Texas. J. Wildl. Manage. 29: 706-716.

McMahan, C.A. 1964. Comparative food habits of deer and three classes of livestock. J. Wildl. Manage. 28: 798-808.

Milford, R., and K.P. Haydock. 1965. The nutritive value of protein in subtropical pasture species grown in southeast Queensland. Aust. J. Exp. Agr. Anim. Hus. 5: 13-17.

Murphy, D.A., and J.A. Coates. 1966. Effects of dietary protein on deer. Trans. N. Amer. Wildl. Conf. 31: 129-138.

National Research Council. 1975. Nutrient requirements of domestic animals; No. 5. Nutrient requirements of sheep. National Academy of Sciences. $72 \mathrm{p}$.

Reichert, D.W. 1972. Rearing and training deer for food habits studies. U.S. Dep. Agr., Forest Serv. Res. Note RM-208. 7 p.

Smeins, R.E., T.W. Taylor, and L.B. Merrill. 1976. Vegetation of a 25-year exclosure on the Edwards Plateau of Texas. J. Range Manage. 29: 24-29.

Taylor, C.A., and F.C. Bryant. 1977. A durable esophageal cannula for sheep and goats. J. Range Manage. 30: 397-398.

Thompson, C.B., J.B. Holter, H.H. Hayes, H. Silver, and W.E. Urban, Jr. 1973. Nutrition of white-tailed deer. I. Energy requirements of fawns. J. Wildl. Manage. 37: 301-311.

Ullrey, D.E., W.G. Youatt, H.E. Johnson, L.D. Fay, and B.L. Bradley. 1967. Protein requirements of white-tailed deer fawns. J. Wildl. Manage. 31: 679-785.

Ullrey, D.E., W.G. Youatt, H.E. Johnson, L.D. Fay, B.L. Schoepke, and W.T. McGee. 1969. Digestible energy requirement for winter maintenance of Michigan white-tailed does. J. Wildl. Manage. 33: 482-490.

Van der Westhuysen, J.M., and C.S.M.B. Roelofse. 1971. Effect of shelter and different levels of dietary energy and protein on reproductive performance in Angora goats with special reference to the habitual aborter. Agroanimalia. 3: 129-132.

Van Soest, P.J. 1967. Development of a comprehensive system of feed analysis and its application to forages. J. Anim. Sci. 26: 119-128.

Van Soest, P.J. 1970. Chemical basis for the nutritional evaluation of forages. Proc. Nat. Conf. on Forage Qual. Eval. and Util., Lincoln, Neb., 1969. p. U1-U19.

Wilson, A.D. 1976. Comparison of sheep and cattle grazing on semi-arid grassland. Aust. J. Agr. Res. 27: 155-162.

Wilson, A.D., N.C. Weir, and D.T. Torrell. 1971. Evaluation of chamis (Adenostoma fasiculatum) and interior live oak (Quercus wizlizenii) as feed for sheep. J. Anim. Sci. 32: 1042-1050.

CHANGE OF ADDRESS notices should be sent to the Managing Editor, 2760 West Fifth Ave., Denver, Colo. 80204, no later than the first day of the month of issue. Copies lost due to change of address cannot be replaced unless adequate notice is given. To assure uninterrupted service, provide your local postmaster with a Change of Address Order (POD Form 3575) indicating thereon to guarantee forwarding postage for second-class mail. 